J. Lake Sci. (湖泊科学), 2014, 26(2): 169-176

http: //www. jlakes. org. E-mail : jlakes@niglas.ac.cn

(C) 2014 by Journal of Lake Sciences

\title{
湖库生态安全调控技术框架研究
}

\author{
郑丙辉 ${ }^{1,2}$, 王丽婧 ${ }^{1,2}$, 李 虹 ${ }^{1,2}$, 李小宝 ${ }^{1,2}$ \\ (1: 中国环境科学研究院,环境基准与风险评估国家重点实验室,北京 100012) \\ (2: 中国环境科学研究院,国家环境保护饮用水水源地保护重点实验室,北京 100012)
}

摘 要: 针对湖库生态安全综合性调控技术缺乏的现状, 为支撑和保障湖库型水体生态安全, 开展了湖库生态安全调控 概念、特征及技术需求分析, 研究并系统构建了湖库生态安全调控技术框架 (T-PIRLEP), 阐述和分析了该框架的主要技 术环节. 根据研究结果, 认为湖库生态安全具备可调控的特性, 调控目的旨在维护以人类为终点的湖库生态环境和生态 服务的安全. 湖库生态安全调控具有综合性、功能导向性、类型差异性、空间异质性和不确定性的特征. 基于 T-PIRLEP 的 调控技术框架以湖库生态安全保障目标 $(\mathrm{T})$ 为核心, 以生态承载力为重要约束参考, 从影响湖库生态安全状况的人口增 长一产业发展一资源利用一污染排放一生态保护-政策管理的耦合作用过程出发, 采取以人口调控 (P)、产业调控 (I)、资源 利用调控 $(\mathrm{R})$ 、负荷控制 $(\mathrm{L})$ 、生态调控 $(\mathrm{E})$ 、政策调控 $(\mathrm{P}) 6$ 类要素为主的调控措施来实现湖库生态安全调控. 研究指出, 调控过程需以湖库调控类型和其调控定位为引导, 注重调控目标、调控措施、目标可达性分析之间的相互反馈, 强化与生 态安全评估研究的有机衔接.

关键词: 湖泊;水库;生态安全调控;T-PIRLEP 技术框架;调控措施

\section{Technical framework for ecological security control in lakes and reservoirs}

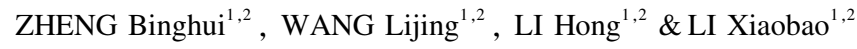

(1: State Key Laboratory of Environmental Criteria and Risk Assessment, Chinese Research Academy of Environmental Sciences, Beijing 100012 , P. R. China)

2: State Environmental Protection Key Laboratory of Drinking Water Source Protection, Chinese Research Academy of Environmental Sciences, Beijing 100012, P. R. China)

\begin{abstract}
With a view to the lack of comprehensive control technology for ecological security (ES) of lakes and reservoirs, also for supporting and ensuring their ecological security, the concept, characteristics and technical requirements for ecological security control (ESC) were firstly analyzed. Meanwhile, ESC technical framework (T-PIRLEP) was studied and proposed. Technical points for main elements of the framework were also presented to approach ESC. According to the results of this study, it is considered that ES of lakes and reservoirs is controllable and the main objectives of ESC are to maintain the safety of eco-environment and eco-service in lakes and reservoirs with the endpoint of human safety. ESC has features like comprehensive, function-oriented, type diversity, spatial dynamics and uncertainty. In the T-PIRLEP framework, target of ensuring ecological security ( T) is regarded as the core element and the ecological carrying capacity is considered as an important constraint. In view of the coupled inter-reaction of different affecting elements of ES, such as population growth, industry development, resource utilization, pollution emissions, ecological protection and policy management, 6 kinds of regulating and control measures including population regulation $(\mathrm{P})$, industry regulation $(\mathrm{I})$, resources use regulation $(\mathrm{R})$, load control $(\mathrm{L})$, ecological regulation $(\mathrm{E})$ and policy regulation $(\mathrm{P})$ are finally suggested to realize the ESC for lakes and reservoirs. The research indicates that targeting specifically on different control types should be carried out to guide the whole regulation process. Mutual feedbacks among control target, regulation measures, and target reachability analysis should be highlighted, and the convergence between ES assessment and control should be strengthened in the regulation research.
\end{abstract}

* 国家水体污染控制与治理科技重大专项项目 (2012ZX07503-002)、国家重点基础研究发展计划 “973” 项目 (2012CB417004) 和全国重点湖库生态安全调查及评估专项项目 (2008-2010 年) 联合资助. 2013-05-07 收稿; 2013-09-28 收修改稿. 郑丙辉(1963 ), 男, 博士, 研究员; E-mail : zhengbh@ craes. org. cn. 
Keywords: Lake; reservoir; ecological security control;T-PIRLEP technical framework; regulation measure

湖泊和水库是水体的重要存在形式, 具有供水、灌溉、渔业、景观、防洪等多种功能, 在居民日常生产生 活、区域社会经济发展中扮演重要角色 ${ }^{[1]}$. 作为一种全新的管理目标, 湖库生态安全是支撑和保障湖库流域 社会经济一环境持续发展的重要途径,代表了水环境管理从水质管理向水生态管理转变的发展方向. 1990s 以来, 随着污染排放、生态破坏等人类干扰活动的加剧, 湖泊水库富营养化等问题日益凸显, 湖库生态安全 问题亦愈渐受到人们的重视 ${ }^{[2-3]}$. 相应地, 国内外学者开始在生态安全评价、生态承载力、流域综合管理等相 关方面进行诸多探索. 上述研究虽然从不同角度触及湖库生态安全管理这一领域, 但从技术层面上, 侧重评 估类问题诊断技术居多 ${ }^{[1,4-6]}$, 涉及调控类保障和管理技术偏少; 从内容层次上, 侧重某一单项要素的调控研 究居多 (如产业结构、土地利用、环境容量) ${ }^{[7-9]}$, 涉及生态安全综合层面的调控研究鲜有; 从研究对象上, 专 门针对湖库型水体的相关研究亦不多 ${ }^{[4-6]}$; 总体上尚未从保障湖库型水体生态安全的角度研究构建系统性、 综合性的调控技术方法.

湖库生态安全调控 (ecological security control for lakes and reservoirs) 是保障湖库生态安全的关键途径, 是支撑和实现湖库生态安全管理的基石和依托. 近年来, 国家财政部、环境保护部组织实施的全国重点湖库 生态安全调查及评估专项、水质良好湖泊生态环境保护专项为湖库生态安全管理相关技术研发带来了重要 契机. 作者所在课题组依托上述专项开展了湖库生态安全调控技术的研究, 其成果被纳人《湖库生态安全保 障方案编制技术指南》1 和《良好湖泊生态环境保护专项——湖泊生态环境保护实施方案编写指南》 (2) 在 9 个大型湖库及 30 个良好湖泊生态环境保护中得以实践. 该研究在前期课题成果总结、应用及反馈完善基础 上, 围绕湖库生态安全保障需求, 着眼于影响湖库生态安全的人口增长一产业发展一资源利用一生态保护一监 督管理等要素耦合作用过程, 构建湖库生态安全调控技术框架, 并对框架相关技术要点进行分析阐述.

\section{1 湖库生态安全调控概念辨析}

湖库生态安全的概念内涵是开展湖库生态安全调控研究的基础. 生态安全的概念由国际应用分析研究 所 (IASA) 于 1989 年首次明确提出. 1990s 国内开始关注生态安全并积极开展大量相关研究. 虽然目前生态 安全的概念尚无统一的认识, 但在生态环境领域, 其大致分为以生态系统为终点的安全和以人类为终点的 安全两类 ${ }^{[10-12]}$. 前者注重生态系统的健康、完整性和可持续性, 后者关注人类生存环境的安全、所需要的生 态服务的安全.

该研究强调生态安全应以人为本的特质, 倾向于以人类为终点的安全概念. 湖库生态安全可定义为人 类赖以生存和发展的湖库生态系统处于健康状态、面临低生态风险, 生态系统服务功能良好且可持续 ${ }^{[1,13]}$. 生态系统是否安全以人类所要求的生态因子或生态服务的质量来衡量. 影响生态安全的因素很多, 若其中 一个或几个要素不能满足人类生存与发展的需求, 可认为生态系统不安全.

该研究认可生态安全能够调控的特性, 但侧重于针对人为干扰带来的湖库生态安全不利影响进行调 控, 长期自然演化或不可抗力因素导致的问题则做特殊考虑. 湖库生态安全调控是指为维持或改善湖库生 态安全状况, 以湖库生态安全调控目标为导向, 针对影响湖库水生态安全的要素进行调控管理的过程. 不安 全的状态和区域, 可以采取措施加以减轻, 降低或解除生态环境风险, 改善湖库生态系统功能. 但维护生态 安全、减少来自于人类活动的生态风险往往需要付出代价, 寻找社会经济发展、资源利用的 “妥协”行为 方式.

该研究强调生态安全调控与生态安全评价之间的有机联系. 两者均是生态安全管理技术体系的有机组 成部分. 生态安全评价有助于诊断生态安全存在的问题, 定性或定量了解生态系统安全状况并识别其变化 趋势, 能够为实施生态安全针对性调控和管理提供技术支持 ${ }^{[1,4,14]}$. 生态安全调控则需要建立在生态安全问

(1) 中国环境科学研究院. 湖库生态安全保障方案编制技术指南. 环境保护部项目,2009.

(2) 中国环境科学研究院. 良好湖泊生态环境保护专项——湖泊生态环境保护实施方案编写指南. 环境保护部项目, 2012. 
题识别和评估基础上,基于生态安全评估来确定调控思路、目标和重点,并依托其来反馈判断调控措施的预 期和实际效果.

\section{2 湖库生态安全调控特征及技术需求}

着眼于湖库生态系统的特征和生态安全保障需求分析,湖库生态安全调控具有综合性、功能导向性、类 型差异性、空间异质性、不确定性调控管理等特点. 构建和应用湖库生态安全调控技术框架时需要对上述特 点和需求予以反映.

(1) 调控管理的综合性. 湖库生态系统是一个综合性复杂巨系统. 在系统组成上以水体为中心, 涵盖湖区 (库区) 及其上游流域社会、经济、资源、环境、政策等诸多要素; 在空间范围上覆盖面积较广,多涉及不同省 市行政单元. 系统内各种要素相互作用和影响,具有高度非线性、动态性、复杂反馈性等系统学行为特征. 据 此,决定了湖库生态安全调控管理必须立足于 “综合性”, 遵循从流域到水体、源头一途径一汇的“过程管理” 原则,避免 “就湖库论湖库”; 仅针对水体或某个单项要素进行调控, 背离了湖库生态系统的特征, 其目标往 往难以实现.

(2) 调控管理的功能导向性. 湖库往往具有不同的功能类型,包括主导功能和辅助功能. 调控管理需要突 出功能导向对调控措施制定的引导. 对于特定功能类型的湖库, 其湖库生态安全调控管理应以保障和维护 主导功能为核心导向. 譬如, 以饮用水供给为主的湖库,优先保护饮用水水源地水质是关键,水源保护区的 划分和保护、流域水污染防治、水质保护长效机制的建立等均需突出饮用水源地这一敏感目标的保护. 对于 综合性服务功能显著的湖库, 当多种功能对水体要求发生冲突时, 应执行最高目标管理原则. 譬如某水域是 工业用水、渔业养殖区,亦是备用水源地,则调控管理要求执行水源地水质目标.

(3) 调控管理的类型差异性. 湖库生态系统所处的安全水平 (安全、一般安全、不安全)、生态系统演变阶 段 (如人为活动导致的富营养化不同阶段、生态系统发育阶段等 $)^{[1]}$ 决定了其调控管理需求的差异性. 调控 技术方法及其实际应用需要突出调控类型差异对措施建议、措施笁选优化的引导. 借鉴世界湖泊环境委员 会 (ILEC) 的划分理念,将湖库调控管理类型归纳为预防型、治理型和恢复型 ${ }^{[15-16]}$. 预防型湖库主要针对安全 水平较好、富营养化程度较低 (贫一中营养) 的湖库,其调控管理需要重点实现流域人类社会经济活动的压力 与湖库生态环境保护的统筹协调、和谐共生,从而维护和改善生态安全状况. 治理型湖库主要针对安全水平 一般或较差、富营养化程度一般(中一轻富营养)的湖库,人类社会影响已对水体表现出显著干扰,其调控管 理需要在全面协调社会经济与环境保护关系的基础上,重点开展针对性治理,改善和恢复生态环境. 恢复型 湖库主要针对安全水平差或极差、富营养化程度严重 (中富一富营养) 的湖库,其湖库功能受到人类活动严重 影响而无法正常发挥、甚至完全丧失,需要在实施预防、治理的同时,采取强有力的综合措施对湖库进行抢 救性恢复. 譬如, 滇池生态安全状况属于极不安全,水质超 $\mathrm{V}$ 类, 营养指数达重度富营养化, 大面积水华进人 常态化, 饮用水源功能基本丧失, 应归类为 “恢复型”湖库,需进行全面的控源、治污与生态修复, 重建人一湖 和谐的生态系统 ${ }^{[17]}$.

(4) 调控管理的区域差异性. 从自然环境角度,受湖库形态特征、水流强度、分层特征的影响,湖库具有空 间异质性. 譬如,理论上水库从库尾至库首的水平方向上依次存在 3 个区域,即河流区、过渡区和湖泊 区 $^{[1,18-22]}$. 不同的水库及不同调度运行期各区空间范围不同,其物理环境及水化学、水生生物环境差异较显 著,对人类干扰的敏感性、耐受性亦有差异. 从人为影响角度,由于人口、产业和土地开发布局等差异, 人类 干扰程度存在空间差异,局部水域可能受影响更大,生态安全问题更突出. 调控技术方法及其实际应用需要 考虑空间差异性,并据此引导调控措施的分区制定. 例如, 我国三峡水库成库后, 支流水域类似湖泊生态环 境,在与干流同等的营养盐浓度水平下更易发生水华,其调控管理需重点关注支流敏感水域的问题改善; 太 湖流域的社会经济发展及污染排放的空间差异特征显著,其调控管理应重点关注北部、湖西、浙西等重污染 区域 ${ }^{[17-18]}$.

(5) 调控管理的不确定性. 在自然演替规律和人类干扰双重作用下,湖库生态系统一直处于动态变化过 程中. 未来湖库生态安全状况的发展趋势、压力风险、政策措施及其有效性等均存在不确定性. 调控技术方 法及其实际应用需要保持调控管理过程的动态性、信息开放性和适应性,确保湖库生态安全的调控处于动 
态调整过程,能够针对不确定的环境变化、新的政策信息不断调整相关调控措施来适应管理需要.

\section{3 基于 T-PIRLEP 的湖库生态安全调控技术框架}

湖库生态安全调控技术框架是协助湖库生态安全调控思路建立、引导调控措施制定、实施和动态调整 湖库生态安全调控管理的统领性技术工具.

在湖库生态安全概念辨析、调控管理特征及技术需求分析的基础上,该研究提出了湖库生态安全调控 的技术框架 (T-PIRLEP) (图 1). 根据该框架, 湖库生态安全调控的技术步骤主要包括: 在生态安全问题识 别、生态安全评估等成果的基础上,明确调控对象、保护目标; 结合研究实际, 确定湖库生态安全调控类型和 调控管理定位, 根据实际开展调控管理分区; 初步确定湖库生态安全保障的目标 (target); 围绕调控目标, 结 合生态承载力研究, 从影响湖库生态安全状况的人口增长一产业发展一资源利用一负荷控制一生态保护一政策 管理 (population-industry-resources-load-ecosystem-policy, PIRLEP) 的耦合作用过程出发, 笁选优化湖库生态安 全调控措施; 反馈分析调控方案的目标可达性, 进行目标或措施调控; 重复上述步骤直至湖库生态安全调控 目标可达,输出形成调控方案. 框架相关要素解析如下:

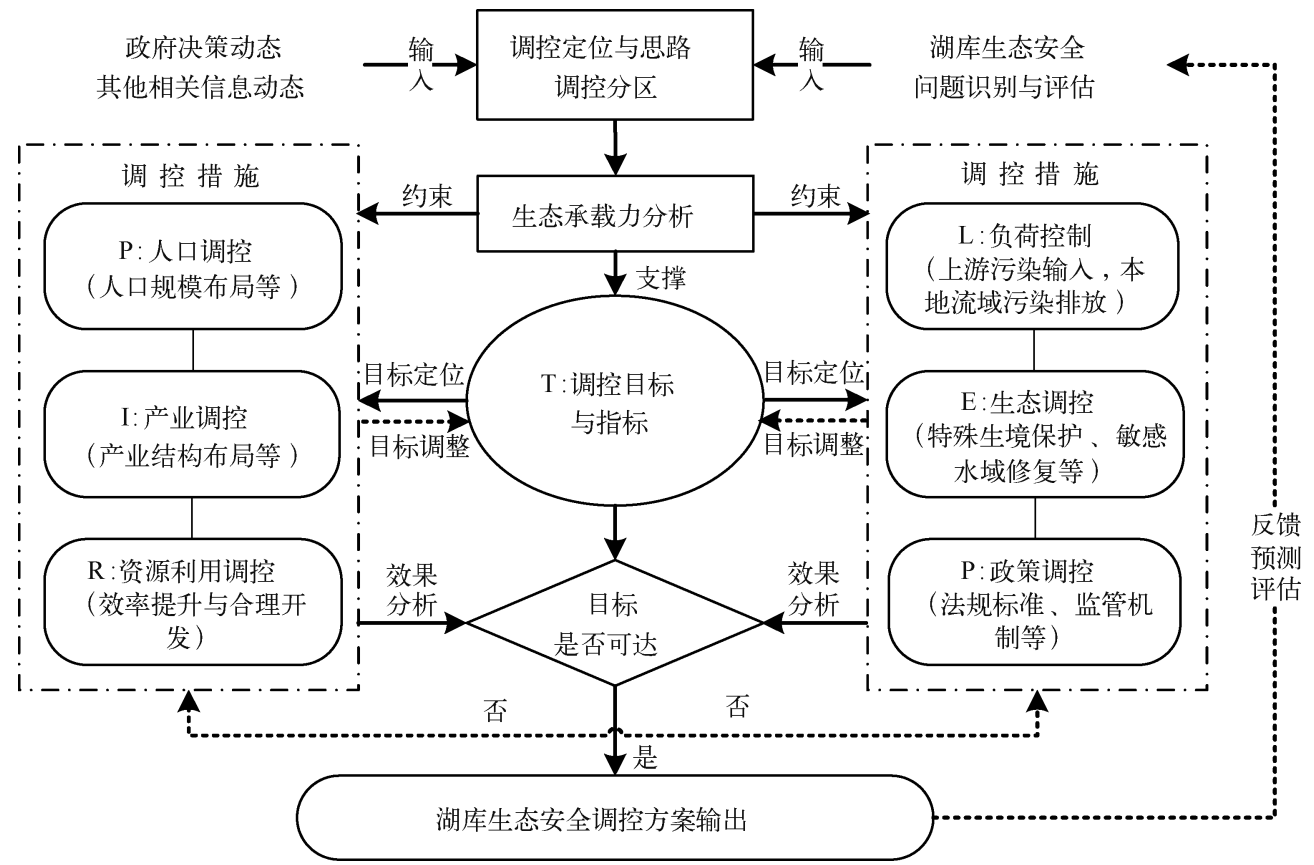

图 1 湖库生态安全调控技术( T-PIRLEP) 框架

Fig. 1 Technical framework for ecological security control in lakes and reservoirs (T-PIRLEP )

(1) 调控对象与保护对象. 湖库生态安全调控所改善/控制的对象, 是导致湖库生态安全问题的综合性压 力源, 如区域土地开发、生产生活污染排放等. 调控对象一般涵盖于 P-I-R-L-E-P 6 类要素中, 但需要根据湖 库实际情况予以进一步明确和细化, 并建立调控对象优先次序; 超出 6 类要素的调控对象可以参考该框架 单独考虑相关措施. 湖库生态安全调控所保护的对象是通常所指的生态受体, 主要包括人类和水生态系统 (种群、群落、生态系统等不同层次) 两大类有机体. 保护对象可以根据实际进一步收缩, 如饮用水源地水质 等; 保护对象的确定需体现湖库功能的导向性.

(2) 调控定位及调控分区. 湖库生态安全调控定位需要确定湖库生态安全调控类型, 提出调控管理的重 点方向、重点策略和基本定位, 作为指导实施整个调控过程、贯穿调控方案研究的核心和关键. 调控类型的 划分可参照第 2 节的划分方法, 需要在湖库生态安全问题识别和评估的基础上, 进一步分析湖库生态安全 现状及历史变化、主要生态安全问题、水体所处演替阶段、社会经济发展水平及趋势、未来恶化风险等,结合 
政府决策部门及专家意见予以确定. 湖库生态安全调控分区,应基于湖库生态安全状况空间差异,有效结合 水污染防治分区 ${ }^{[23]}$ 、生态功能区划 ${ }^{[24]}$ 、水功能区划 ${ }^{[25]}$ 以及行政管辖边界实施水域和陆域分区. 可以统筹考 虑综合调控要素进行统一分区,亦可针对单项调控要素进行调控分区.

(3) 调控目标. 湖库生态安全调控的基本目标以湖库生态安全水平提高为方向, 以水质、水生态改善为核 心. 调控目标的确定承接对生态安全问题现状及趋势分析成果, 以生态承载力研究为重要参考, 建立在单项 调控措施基础之上, 与各单项措施制定相互反馈、联系. 调控目标必须考虑湖库生态安全调控的功能导向 性、类型差异性、区域差异性和不确定性; 可以采取总体目标和阶段目标,整体目标、单项调控目标和分区调 控目标,宏观目标和具体调控指标等相结合的方式予以表述.

(4) 生态承载力. 生态承载力是保障湖库生态安全的重要约束条件. 流域社会经济活动超过生态承载力 会造成湖库生态系统退化, 导致生态系统不安全. 生态承载力的承载要素有资源要素、环境要素和社会经济 要素,其计算方法亦有诸多探索 ${ }^{[26-29]}$. 该研究中生态承载力的确定倾向于兼顾考虑不同单项要素的承载 力 $^{[27,30-32]}$, 最终寻求社会经济、资源利用与环境保护的合理约束范围,作为保障水体生态安全的基础.

(5) 调控措施. 考虑到湖库生态安全调控管理的“综合性”, 着眼于流域一水体相互作用关系, 遵循过程管 理理念, 设计了以人口调控 $(P)$ 、产业调控 $(I)$ 、资源利用调控 $(R)$ 、负荷控制 $(L)$ 、生态调控 $(E) 、$ 政策调控 (P) 6 类要素为主的调控措施. 调控措施的制定以调控目标为导向, 面向湖库关键问题和优先问题, 可重点 开展某几个领域、某几类要素的调控措施研究; 调控措施不能违背科学发展的客观规律, 脱离区域实际情 况; 调控措施之间应建立有机结合的相互联系,协同服务于湖库生态安全保障. 不同湖库由于其生态系统的 独特性,调控措施的重点内容、管理方案均不相同.

\section{4 湖库生态安全调控措施研究技术要点}

湖库生态安全调控措施是实现湖库生态安全调控目标的依托. 从我国大型湖库生态安全主要问题改善 角度, 针对 P-I-R-L-E-P 6 类调控要素, 提出调控措施研究要点.

\section{1 人口调控}

人口调控要协调流域人口增长与环境支撑之间的相互关系, 依托相关关键因子调控, 控制人口增长所 造成的资源消耗及污染排放在流域所能承载的范围内. 其核心是人口规模、布局、结构等调控.

人口调控过程需要与城镇化进展、产业发展整合起来考虑. 首先, 需要开展人口子系统的综合分析. 包 括梳理流域人口规模、人口结构、人口素质、劳动力就业结构、消费模式等, 分析流域城镇化进程、产业布局 调整对人口规模和布局的影响, 分析人口发展的形势, 识别有待调控解决的问题. 其次, 以生态承载力研究 为参照, 分析人口超载状况, 研究人口数量转移和布局转移、区域承载效率和承载水平提升等调控途径. 再 次, 初步构建人口调控单项目标和衡量指标. 围绕目标, 研究不同情景下的流域人口规模、布局的调控措施, 包括政府作为 (如就业转移基地)、市场化运作 (如劳务输出)、社会保障(如户口政策、教育培训) 等措施. 最 后,分析不同调控措施的目标可达性,提出可行的人口调控方案.

人口调控措施的目标和效果可采用具体指标予以衡量. 按照指示性、数据可得性、独立性等指标笁选原 则,在专家咨询和实践反馈的基础上,确定调控核心指标和参考指标; 核心指标直接反映该要素的调控目 标, 参考指标体现该要素的调控过程控制及直接、间接效益. 据此, 人口调控核心指标主要选取人口增长率、 人口密度、城镇化率; 参考指标为人均 GDP、农民年人均纯收人、城镇居民年人均可支配收人、基尼系数、恩 格尔系数、登记失业率、受教育程度人口比例 (大专以上) 等. $4.2 \sim 4.6$ 节亦参考该方法确定调控指标.

\section{2 产业调控}

流域产业优化调控要协调流域产业发展与环境支撑之间的相互关系, 通过对产业发展模式调控, 尤其 是对构成该发展模式的关键因子的调控来实现资源节约利用和污染物减排的目标, 控制产业发展所造成的 资源消耗并使其污染物排放在流域承载范围之内. 其核心是产业规模、结构和布局调控.

产业调控措施的制定首先需系统分析湖库流域主要产业结构、产业空间布局,分析行业污染排放特征; 其次,结合国家和区域重大发展战略、主体功能区划、社会经济发展规划和环境保护规划,探索与流域资源 承载力、环境容量相适应的产业发展模式, 分析产业结构优化、空间布局调整等调控途径; 提出产业调控单 
项目标和衡量指标, 研究提出产业结构和布局的调控措施,包括推动跨行政区的流域产业布局统筹规划优 化, 推动流域和区域内产业的分工协作, 加快产业结构调整和产业升级, 提高资源能源的利用效率, 推动循 环经济发展等.最后基于目标可达性分析,提出可行的产业调控方案.

产业调控核心指标主要选取 GDP 增长率、第三产业比重、人均 GDP、万元 GDP 排污负荷; 参考指标为万 元 GDP 用水量、万元工业增加值用水量、单位土地面积 GDP、万元 GDP 能耗以及规模以上工业企业单位产 值综合能耗、水耗等.

\section{3 资源利用调控}

流域资源利用调控以流域生态安全保障为导向, 以资源的合理开发、优化配置、高效利用为主要内容, 依据经济效益与社会效益、生态效益相结合的原则, 从流域的资源分布特性、开发利用条件出发, 最大程度 地促进资源利用和生态环境保护的和谐统一. 其核心为水资源调控和土地资源调控.

水资源调控以饮用水源地水量安全保障为重点, 研究流域水资源优化配置模式、用水效率提升和生态 用水保障等调控途径; 通过加强供水和公共用水管理、提高居民生活用水效率、推进农业领域的节水改造技 术和工业领域的高耗水行业节水等措施来实现水资源调控目标. 土地资源调控需在流域土地资源评价 ${ }^{[33]}$ （如适宜性、敏感性评价）、区域土地资源特征差异性综合分析基础上,对不同土地管理类型在空间上进行分 区(譬如, 基于区域发展宏观调控的三峡库区土地管理分区、基于敏感地域保护的三峡库区土地管理分 区 $^{[34]}$ ); 结合国家区域发展战略和生态安全保护需求, 明确不同分区的土地资源开发定位、生态安全管理要 求, 研究调控途径; 通过严格保护流域生态敏感用地、强化流域土地管理水平, 提高土地利用效率等措施来 实现调控目标, 减少人地矛盾, 促进土地资源可持续利用. 不同湖库流域发展的限制性资源不同, 在实际调 控过程中有所侧重.

水资源调控的核心指标主要选取人均用水量、万元 GDP 用水量、农田实灌面积亩均用水量; 参考指标为 人均可利用水资源量、用水比例 (生活、工业、农业、生态)、万元工业增加值用水量、工业用水重复利用率、再 生水回用率、规模以上工业企业单位产值水耗等. 土地资源调控核心指标主要选取受保护地区面积比例、单 位土地面积 GDP; 参考指标为人均耕地面积、森林覆盖率、建设用地面积比例.

\section{4 负荷控制}

污染负荷排放是湖库生态系统的直接压力, 尤其高氮、磷负荷是导致湖库富营养化的重要内因. 流域污 染负荷控制以减轻水体压力为直接目的, 从生态承载力和水环境容量约束出发, 统筹考虑污染负荷排放特 征、流域经济社会发展水平、污染治理技术经济可行性, 研究流域污染物排放总量控制、流域主要污染源削 减等调控措施, 提出针对不同区域、不同污染源类型的流域水污染负荷控制方案 ${ }^{[16]}$. 其核心是外流域污染负 荷控制、本地流域污染排放控制.

负荷控制相对于其他类调控要素而言, 其研究相对成熟. 首先, 需核算并辨析各类污染负荷的来源组 成、空间分布及变化趋势, 识别重点控制对象. 其次, 结合湖库生态安全调控分区、水体水环境容量计算以及 国家或地方相关规划和总量减排计划要求, 确定流域及子区域总量控制目标. 最后综合经济技术可行性等 因素, 结合实际提出污染负荷削减方案及其配套工程措施、政策措施 ${ }^{[16]}$. 值得注意的是, 上游流域来水状况 对入湖 (库) 污染负荷控制具有决定性作用, 如太湖、巢湖人湖河流以 IV 类和劣 V 类水为主 ${ }^{[17]}$, 三峡水库约 $80 \%$ 的人库污染负荷源自上游输人 ${ }^{[35]}$, 上游来水安全需要借助流域统筹管理等政策措施予以优先保障. 同 时, 传统控制措施多以工业和生活点源为重点治理对象, 而非点源污染在湖库流域排污结构中多占优势, 应 给予特别关注. 此外, 大型湖库多具有通航功能,亦需要对船舶污染给予关注.

负荷控制调控核心指标可选取人湖河流污染物通量削减率、流域污染物排放总量削减率; 参考指标为 城镇污水处理率、工业废水处理率、规模化畜禽废物处理率、化肥使用强度、船舶污水收集率、单位土地面积 排污负荷、上游来水水质达标率、湖体水质达标率等.

\section{5 生态调控}

生态调控主要通过物理、化学、生物、工程等方法, 以湖库水域及岸边缓冲带为关注对象, 着力恢复湖库 生态系统生物链, 完善水域生态系统结构, 增强水体的自净能力和生态系统对干扰的抵抗力, 促进水域生态 系统的良性循环. 
湖库生态调控需要在湖库生态安全评估的基础上,深人分析湖库生态安全问题, 明确产生问题的原因, 选择对症的技术方案或技术组合方案实施调控,并评估调控技术的目标可达性. 采取措施的过程中,应对水 体进行跟踪式的生态监测并修改调整方案. 湖库生态调控所涉及的对象范围较为宽泛. 考虑到大型湖库的 水生态系统特征,生态调控建议以湖库特殊生境 (如湖滨带、消落带) 的保护、敏感水域生态系统修复 (如鱼 类栖息地、产卵场、洄游区等,饮用水源保护区)、水华高发区生态修复为调控重点.

生态调控核心指标主要选取饮用水源达标率、天然湖滨带/消落带长度比例、鱼体残毒监测达标率、水 华暴发频率, 用于反映湖库饮用水源、栖息地、水产品等服务功能的改善要求; 参考指标为湖体水质达标率、 湖体营养状态指数、湖体浮游植物多样性指数、渔业产值等.

\section{6 政策调控}

政策调控以流域环境风险最小化、生态安全安全保障为前提, 以提高流域政策管理水平为核心,通过建 立或改进相关管理手段,探索新型管理政策,完善流域政策管理体系;分析各项管理手段的经济技术可行性 与可操作性,形成满足湖库流域需求的有效政策调控方案, 从而引导和规范流域人类生产生活行为.

对于大型湖库而言,流域政策调控需要重点关注几个方面 : (1) 面向湖库上下游统筹管理的流域管理立 法, 建立健全完备的法律制度; (2) 面向湖库上下游统筹管理的流域生态补偿机制和污染损害赔偿机制; (3) 面向大型湖库敏感水域的、更为严格的流动源污染防治规定,如船舶污染物铅封管理; (4) 面向湖库型水 体的、更为全面的总量控制计划及人湖 (库)河流水环境质量考核管理规定; (5) 面向湖库上下游统筹联动的 突发性事故监测预警、应急处理处置能力建设等. (6) 面向水库特殊水体的生态安全管理标准与规范建设,如 水库型水体营养盐分区评价标准 ${ }^{[18]}$ 、水库水环境质量分区评价技术规范等.

政策调控的核心指标可考虑公众对水环境保护满意率、环境政策完善状况、环境政策执行效益; 参考指 标为水源地规范化建设状况、污染源监管能力、风险监控预警能力、事故应急处置能力等.

\section{5 结论}

湖库生态安全调控是保障湖库生态安全的关键途径. 该研究从保障湖库型水体生态安全的角度, 开展 了湖库生态安全调控概念辨析、特征及需求分析, 研究并系统构建综合性的湖库生态安全调控技术框架. 相 关结论如下.

(1) 湖库生态安全调控可定义为为维持或改善湖库生态安全状况, 以湖库生态安全调控目标为导向, 针 对影响湖库生态安全的要素进行调控管理的过程. 湖库生态安全调控概念强调生态安全应以人为本, 其调 控目的旨在维护以人类为终点的生存环境和生态服务的安全; 认可生态安全能够调控的特性, 但强调侧重 于针对人为活动引起的生态安全问题予以调控; 重视生态安全调控与生态安全评价之间的有机联系.

(2) 湖库生态安全调控具有综合性、功能导向性、类型差异性、区域差异性、不确定性调控管理等特点. 相 应地, 调控研究需要遵循流域一水体相互作用的过程管理原则, 实施多要素综合调控; 需要突出湖库主体功 能或最高目标功能对调控目标和措施的导向作用; 需要关注湖库调控类型差异、自然和人为影响的空间差 异产生的不同调控需求,注重其对调控措施篮选优化的引导; 需要保持调控管理过程的动态性、信息开放性 和适应性, 确保湖库生态安全调控过程能够适应不确定的环境和管理需求变化.

(3) 基于 T-PIRLEP 的调控技术框架以湖库生态安全保障目标为核心, 以生态承载力为重要约束参考, 从 影响湖库生态安全状况的人口增长一产业发展一资源利用一负荷控制一生态保护一政策管理的耦合作用过程出 发,设计并采取以人口调控 $(P)$ 、产业调控 $(I)$ 、资源利用调控 $(R)$ 、负荷控制 $(\mathrm{L})$ 、生态调控 $(\mathrm{E})$ 、政策调控 (P)6 类要素为主的调控措施. 调控过程中, 需立足于湖库调控类型和调控定位 (如预防型、治理型或恢复 型),注重生态安全评估、调控目标、调控措施、目标可达性分析之间的有机衔接和反馈分析.

(4) 针对 P-I-R-L-E-P 6 类调控要素, 梳理提出了各类单项调控的目的、核心调控因子、研究思路和主要 调控方向. 湖库调控过程中,在人口和产业调控层面,强调兼顾其规模、布局和结构调控; 在资源调控层面强 调资源的高效利用; 在负荷控制层面需要强化上游来水污染、非点源污染控制; 在生态调控层面更为关注湖 库特殊生境保护和敏感水域修复问题; 在政策管理层面更迫切地需要面向湖库型水体的法规、管理机制和 相关技术规范等. 


\section{6 参考文献}

[ 1 ] 王丽婧, 郑丙辉. 水库生态安全评估方法 (I) :IROW 框架. 湖泊科学, 2010,22(2): 169-175.

[2] 冯 宁, 毛 锋,李晓阳等. 滇池生态安全综合评估研究. 环境科学, 2010,31(2):282-286.

[ 3 ] 邹长新, 沈渭寿. 生态安全研究进展. 农村生态环境, 2003,19(1) :56-59.

[4] 金相灿, 王圣瑞, 席海燕. 湖泊生态安全及其评估方法框架. 环境科学研究, 2012,25(4):357-362.

[5] 张 松, 郭怀成, 盛 虎等. 河流流域生态安全综合评估方法. 环境科学研究, 2012,25(7):826-832.

[ 6 ] 游文䔉,丁惠君,许新发. 鄱阳湖水生态安全现状评价与趋势研究. 长江流域资源与环境, 2009,18(12):1173-1180.

[ 7 ] 姜瑞华. 重庆市生态安全的状态、演化趋势及调控措施研究 [学位论文].重庆:重庆师范大学,2010.

[8] 廖 炜. 丹江口库区土地利用变化与生态安全调控对策研究 [学位论文].武汉:华中师范大学,2011.

[9] 李长安,殷鸿福, 俞立中等. 关于长江流域生态环境系统演变与调控研究的思考. 长江流域资源与环境, 2001, 11 (6) $: 550-557$.

[10] 陈 星,周成虎.生态安全:国内外研究综述. 地理科学进展,2005,24(6):8-17.

[11] 陈国阶. 论生态安全. 重庆环境科学,2002,24(3):1-4.

[12] 杨京平.生态安全的系统分析. 北京:化学工业出版社,2002:129,131-132.

[13] 肖笃宁,陈文波,郭福良. 论生态安全的基本概念和研究内容. 应用生态学报,2002,13(3):354-358.

[14] European Environment Agency. Europe's environment: The second assessment. Oxford: Elsevier Science Ltd, 1998.

[15] Straskraba M, Tundisi JG, Duncan A. State of the art of reservoir limnology and water quality management. Netherlands: Kluwer Academic Publishers, 1993 :213-288.

[16] 王丽婧,翟羽佳,郑丙辉等. 三峡库区及其上游水污染防治规划. 环境科学研究,2012,25(12):61-68.

[17] 中国环境科学研究院. 湖泊生态安全调查与评估. 北京:科学出版社,2012.

[18］郑丙辉,张 远,富 国等.三峡水库营养状态评价标准研究. 环境科学学报,2006,26(6):1022-1030.

$\left[{ }^{1} 9\right.$ ] 林秋奇, 韩博平. 水库生态系统特征研究及其在水库水质管理中的应用. 生态学报,2001,21(6): 1034-1040.

[20] Straskraba M, Tundisi JG. Guidelines of lake management: Volume 9: Reservoir water quality management. International Lake Environment Committee, 1999: 1-60.

[21］富 国. 湖库富营养化敏感分级概念及指标体系研究. 环境科学研究,2005,18(6) : 75-79.

[22] 张 远, 郑丙辉,富 国等. 河道型水库基于敏感性分区的营养状态标准与评价方法研究. 环境科学学报,2006,26 (6) :2016-2021.

[23] 孟 伟.我国流域水环境污染综合防治战略. 中国环境科学,2007,27(5):712-716.

[24] 蔡佳亮,殷 贺,黄 艺. 生态功能区划理论研究进展. 生态学报,2010,30(11):3018-3027.

[25] 袁弘任. 水功能区划方法及实践. 水利规划与设计,2003,(2):19-24.

[26] 景跃军, 陈英姿. 关于资源承载力的研究综述及思考. 中国人口. 资源与环境,2006,16(5):11-14.

[27] 王 俭,孙铁珩,李培军等. 环境承载力研究进展. 应用生态学报,2005,16(4): 768-772.

[28］韦惠兰,刘晨烨. 经济承载力初探. 生态经济,2012,(2):31-34.

[29］毛汉英,余丹林. 区域承载力定量研究方法探讨. 地球科学进展,2001,16(4):549-555.

[30］王 宁,刘 平,黄锡欢. 生态承载力研究进展. 生态农业科学, 2004,20(6):278-281,385.

[31] 高 路,张宏业. 生态承载力的国内外研究进展. 中国人口・资源与环境,2007,17(2):19-26.

[32] 王树通,郭怀成,王丽婧. 北京市相对资源承载力分析. 安全与环境学报,2005,5(5):90-94.

[33] 王丽婧,席春燕,付 青等. 基于景观格局的三峡库区生态脆弱性评价. 环境科学研究,2010,23(10):48-53.

[34] 王丽婧, 席春燕,郑丙辉. 三峡库区流域水环境保护分区研究. 应用生态学报,2011,22(4):1039-1044.

[35] 郑丙辉, 王丽婧, 龚 斌. 三峡水库上游河流人库面源污染负荷研究. 环境科学研究,2009,22(2):125-131. 